\title{
SPONTANEOUS MAST CELL TUMOR IN NINE CASES OF MICE
}

\author{
Hijiri Iwata, Makoto Enomoto, Yasuhiko Hirouchi, and Yoshihide Koike \\ Biosafety Research Center, Foods. Drugs, and Pesticides
}

\begin{abstract}
Nine mast cell tumors were found in 4,000 mice used in chronic toxicological tests or carcinogenicity tests. Seven cases were diagnosed as malignant mastocytosis and the other two cases were diagnosed as mastocytoma. These neoplastic mast cells had a slightly larger cytoplasm and clear nuclei as compared with the normal mast cells, but their cytoplasmic granules showing a marked metachromasia by toluidine-blue stain were very fine similar to those of normal mast cells. Consequently. these cells were considered to be well-differentiated. The incidence of mast cell tumor was higher in the male than in female mice. Other features of mast cell tumors in mice were : a paucity of infiltration of cosinophils. proliferation of collagen fibers, edema, and other stromal reaction, were considered to be characteristic as compared with the mast cell tumors in other animals. (J Toxicol Pathol 1 : 1 6. 1988)

Key words : Malignant mastocytosis, Mastocytoma. Mice
\end{abstract}

\section{Introduction}

Mast cell tumors in mouse are known to be induced by certain chemicals. Dunn and Potter reported the mast cell tumors in DBAf/ 2 mice by painting of $0.2 \%$ methylcholanthrene ${ }^{1}$, and Frith et al. described a few mast cell tumors which were induced by 2-acetylaminofluorene in mice of BALB/cStCrlBR strain ${ }^{2}$. Carcinogenic shale oils $^{3}$ and cigarette-tars ${ }^{4}$ induced mast cell tumors at the application site of the skin in mice of $\mathrm{CAF}_{1} /$ $J$ and ARS-HA (ICR) strain or random-bred mice. Furth et al. reported the mast cell tumors in $\mathrm{LAF}_{1}$ mice by irradiation ${ }^{5}$. Some of these mast cells have been kept as a transplantable tumor. However, the hitherto reported cases of spontaneous mast cell tumor were rather rare in mice. There were only a few records including those by Deringer et al. (1947)', Dunn (1969)7 , and Lewis et al. (1984). This paper describes nine cases of mast cell tumor, which were observed in mice used

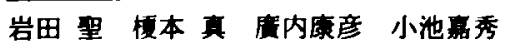

Accepted for publication: December 1, 1987

Mailing address : Hijiri Iwata, Biosafety Research Center, Foods, Drugs and Pesticides, 582-2, Arahama, Shioshinden, Fukude-cho, Iwata-gun. Shizuoka Prefecture, 437-12, Japan. in chronic toxicological tests and carcinogeicity tests in our Center.

\section{Materials and Methods}

Mast cell tumors were found in nine cases out of approximately 4,000 mice (2,000 male mice and 2,000 female mice) which were used for chronic toxicological tests and carcinogenicity tests. Eight cases were observed in $\mathrm{B6C} \mathrm{F}_{\mathfrak{1}}$ (C57BL) $6 \mathrm{CrSlc} \times \mathrm{C} 3 \mathrm{H} / \mathrm{HeSlc}$ ) strain mice and one case in BDF $_{1} \quad$ (C57BL/6NCrj $\times$ DBA/2NCrj) strain mouse. These animals were sacrificed or moribund dead in a period between 52 weeks and 104 weeks of examinations. During the examinations, the animals were housed individually in suspended stainless steel wire-mesh cages in light, humidity and temperature, controlled rooms. Free access to food and tap water was provided. General blood examination, differential calculation of leukocytes and biochemical examination of both blood and urine were carried out in two out of nine cases of mast cell tumors. Tissues from these animals were fixed in $10 \%$ buffered formalin, embedded in paraffin, cut and stained with hematoxylin and eosin (H.E.). Sections of mast cell tumors were stained with toluidine-blue, alcianblue, periodic acid-Schiff, and A.F.O.G. for 
identifying the mast cells through staining reactions of their cytoplasmic granules. Histochemical identification of the mast cell was also carried out on histamine by using orcein-water blue. heparin, and serotonin (5-HTA) for each case. A few cases of mast cell tumors were examined by electron-microscopy on formalin fixed materials after refixation in phosphatebuffered $1 \%$ glutaraldehyde fixatives with postosmification in $1 \% \mathrm{OsO}_{4}$ solution?

\section{Results}

Mast cell tumors were found in nine cases out of 4.000 mice $(0.23 \%)$ : eight cases developing in 2,000 male mice $(0.40 \%)$ and one case in 2.000 female mice $(0.05 \%)$. Consequently, a higher incidence was seen in male mice than in female for the mast cell tumor.

No characteristic clinical symptom was observed in general, except for inhibition of body weight gain and depressed activity in a few of them. Results of the general clinical examinations, which were performed in two cases revealed a data almost within normal range (Table 1 ).

Grossly, the spontaneous lesions including atrophy of the thymus, nodules in the liver or lungs and hyperplasia of the spleen were found. A nodular mass measuring $5 \mathrm{~mm}$ in diameter was observed in the spleen of one case and a white patch measuring $2 \times 2 \mathrm{~mm}$ was seen in the kidney of one case.

Histologically, seven cases were diagnosed as malignant mastocytosis (systemic mastocytosis) and two cases were diagnosed as mastocytoma. Proliferative changes of the mast cells were observed most frequently in the sinus of red pulp of the spleen and sinusoids of the liver and capillary spaces of the bone marrow in seven cases of malignant mastocytosis. Further, these lesions were also observed in the stromal areas of cortex, in some glomeruli of the kidney, mucosal layers of the stomach, dermis or subcutaneous tissue of the skin, sinus of the lymph nodes, and alveolar capillary wall of the lung. Infrequently, they were observed in the mucosa of duodenum and in pancreas and testis (Table 2).

In the proliferative foci, mast cells formed a mass or a diffuse lesion consisting of many cells or
Table 1. The Clinical-Pathological Examination of Two Cases in Mice

\begin{tabular}{|c|c|c|c|}
\hline \multicolumn{4}{|c|}{ Hematology } \\
\hline & & Case 1 & Case 2 \\
\hline WBC & $\left(\times 10^{3} / \mathrm{mm}^{3}\right)$ & 2 & 1.9 \\
\hline $\mathbf{R B C}$ & $\left(\times 10^{2} / \mathrm{mm}^{2}\right)$ & 7.99 & 8.92 \\
\hline HBG & $(g / d])$ & 14.0 & 14.1 \\
\hline HCT & (\%) & 36.9 & 39.1 \\
\hline MCV & $\left(\mathrm{mm}^{2}\right)$ & 46.9 & 43.7 \\
\hline $\mathrm{MCH}$ & (mmg) & 17.5 & 15.8 \\
\hline MCHC & (\%) & 37.9 & 36.0 \\
\hline PLT & $\left(\times 10^{0} / \mathrm{mm}^{2}\right)$ & 1328 & 1545 \\
\hline \multicolumn{4}{|c|}{ Blood chemistry } \\
\hline & & Case 1 & Case 2 \\
\hline Glu. & $(\mathrm{mg} / \mathrm{dl})$ & 95 & 61 \\
\hline BUN & (mg/dl) & 37 & 29 \\
\hline U.A & $(\mathrm{mg} / \mathrm{dl})$ & 3.1 & - \\
\hline I.P & $(\mathrm{mg} / \mathrm{dl})$ & 5.7 & - \\
\hline $\mathbf{T}-\mathbf{P}$ & $(\mathrm{g} / \mathrm{dl})$ & 5.2 & 5.6 \\
\hline Alb. & $(\mathrm{g} / \mathrm{dl})$ & 3.4 & 3.5 \\
\hline T-chol. & (mg/dl) & 127 & 145 \\
\hline ALP & $(I U / L)$ & 30 & 41 \\
\hline s-GPT & (IU L) & 16 & 25 \\
\hline s-GOT & $(\mathbf{I U} / \mathbf{L})$ & 52 & 49 \\
\hline Cho-E & $(I U / L)$ & 8584 & - \\
\hline
\end{tabular}

Differential leukocyte count

$\begin{array}{lcc}\text { (\$) } & \text { Case 1 } & \text { Case 2 } \\ \text { Neut. } & 38 & 23 \\ \text { Lymph. } & 62 & 77 \\ \text { Mono. } & 0 & 0 \\ \text { Eosin. } & 0 & 0 \\ \text { Baso. } & 0 & 0 \\ \text { other } & 0 & 0\end{array}$

\begin{tabular}{lcc} 
Urinalysis & Case 1 & Case 2 \\
PH & 6 & 6 \\
Oocult blood & $(-)$ & $(-)$ \\
Ketones & $(-)$ & $(-)$ \\
Glucose & $(-)$ & $(-)$ \\
Protein (mg/dl) & 100 & 30 \\
Bilirubin & $(-)$ & $(-)$ \\
Urobilinogen & $(+1)$ & $(-)$ \\
\hline
\end{tabular}

a small mass containing few cells (Figs. 1 3). Little difference was seen in the shape and size of cytoplasms and nuclei of these cells. Large, round or pleomorphic cytoplasms were slightly basophilic by H.E. stain. The nucleus was situ- 
Iwate, Enomoto, Hirouchi, et al.

Table 2. Individual Case History and Distribution of Mast Cell Tumors in Nine Cases

\begin{tabular}{|c|c|c|c|c|c|c|c|c|c|}
\hline & Case 1 & Case 2 & Case 3 & Case 4 & Case 5 & Case 6 & Case 7 & Case 8 & Case 9 \\
\hline Strain & B6C3F & $\mathrm{B}_{6} \mathrm{C}_{3} \mathrm{~F}_{1}$ & $\mathrm{B6C} 3 \mathrm{~F}_{1}$ & $\mathrm{BDF}_{1}$ & ${\text { B6C } 3 F_{1}}$ & $\mathrm{~B}_{6} \mathrm{C}_{3} \mathrm{~F}_{\mathrm{t}}$ & $\mathrm{B}_{6} \mathrm{C}_{3} \mathrm{~F}_{1}$ & B6C $3 F_{1}$ & $\mathrm{~B}_{6} \mathrm{C}_{3} \mathrm{~F}_{1}$ \\
\hline Sex & $\delta$ & $\delta$ & $\hat{\delta}$ & $\hat{\delta}$ & $\delta$ & $\hat{\delta}$ & $\hat{\delta}$ & 우 & $\hat{\delta}$ \\
\hline Age (weeks) & 57 & 109 & 109 & 109 & $\begin{array}{c}102 \\
\text { (moribund) }\end{array}$ & 109 & 83 & 109 & $\begin{array}{c}101 \\
\text { (dead) }\end{array}$ \\
\hline Administration & 100 & 1 & control & control & 2,700 & control & control & 300 & 300 \\
\hline \multicolumn{10}{|c|}{ Distribution (histopathology) } \\
\hline Liver & + & + & + & \# & & 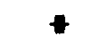 & + & & \\
\hline Spleen & \# & + & + & \# & + & + & + & & \\
\hline Bone marrow & + & + & & \# & + & - & + & & \\
\hline Lung & + & & & + & & + & + & & \\
\hline Kidney & & & & + & + & 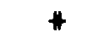 & $\#$ & & \\
\hline Stomach & & & & & $\#$ & \# & \# & & \\
\hline Skin/Subcutis & & & & & \# & + & + & & + \\
\hline Lymph node & & & & + & + & + & & & \\
\hline Duodenum & & & & & & + & & & \\
\hline Pancreas & & & & & & & + & & \\
\hline Testis & & & & & & + & & & \\
\hline Pleura & & & & & & & & * & \\
\hline Diagnosis & $\longleftarrow$ & - & \multicolumn{3}{|c|}{ Malignant mastocytosis } & $\ldots$ & $\longrightarrow$ & \multicolumn{2}{|c|}{$\leftarrow$ Mastocytoma $\rightarrow$} \\
\hline
\end{tabular}

$+=$ minimal infiltration $\quad$ \# = moderate infiltration

+ = marked infiltration

Table 3. Histochemical Characteristics of Mast Cells in Nine Cases

\begin{tabular}{|c|c|c|c|c|c|c|c|c|c|}
\hline & Case 1 & Case 2 & Case 3 & Case 4 & Case 5 & Case 6 & Case 7 & Case 8 & Case 9 \\
\hline $\begin{array}{l}\text { Toluidine blue } \\
\text { (metachromasia) }\end{array}$ & $\#$ & \# & \# & \# & $\#$ & \# & \# & \# & $\#$ \\
\hline Alcian blue & \# & \# & \# & H & + & H & \# & \# & 1 \\
\hline P.A.S. & + & + & - & + & + & \pm & \pm & - & 1 \\
\hline $\begin{array}{l}\text { A.F.O.G. } \\
\text { aniline blue }\end{array}$ & + & + & + & + & + & + & + & + & I \\
\hline fuchsin & + & + & + & + & + & - & - & - & / \\
\hline Histamine & + & + & + & + & + & + & + & + & I \\
\hline Heparin & - & - & - & + & + & + & + & - & / \\
\hline $\begin{array}{l}\text { Serotonin } \\
\text { (5-HTA) }\end{array}$ & \pm & \pm & - & + & \# & - & - & - & I \\
\hline
\end{tabular}

ated in the center and usually clear without heterochromatin and had one or few nucleoli. Mitosis was scarcely found. In a part of these cells, there were vacuolar changes of the cytoplasm (Fig. 4b). These cells had abundant fine granules showing marked metachromasia in the cytoplasm by toluidine-blue stain (Fig. 4a). The other histochemical characteristics of mast cells are shown in Table 3. The point of interest was that histamine was demonstrated in all cases by histochemical examination.

Two cases, which were diagnosed as mastocytoma, showed massive cell accumulation consisting of monotonous cells. One case was found in the mediastinum adjacent to the pleura and another case in the dermis of the skin.

Electron-microscopic observation revealed mast cells containing a fine granular structure 

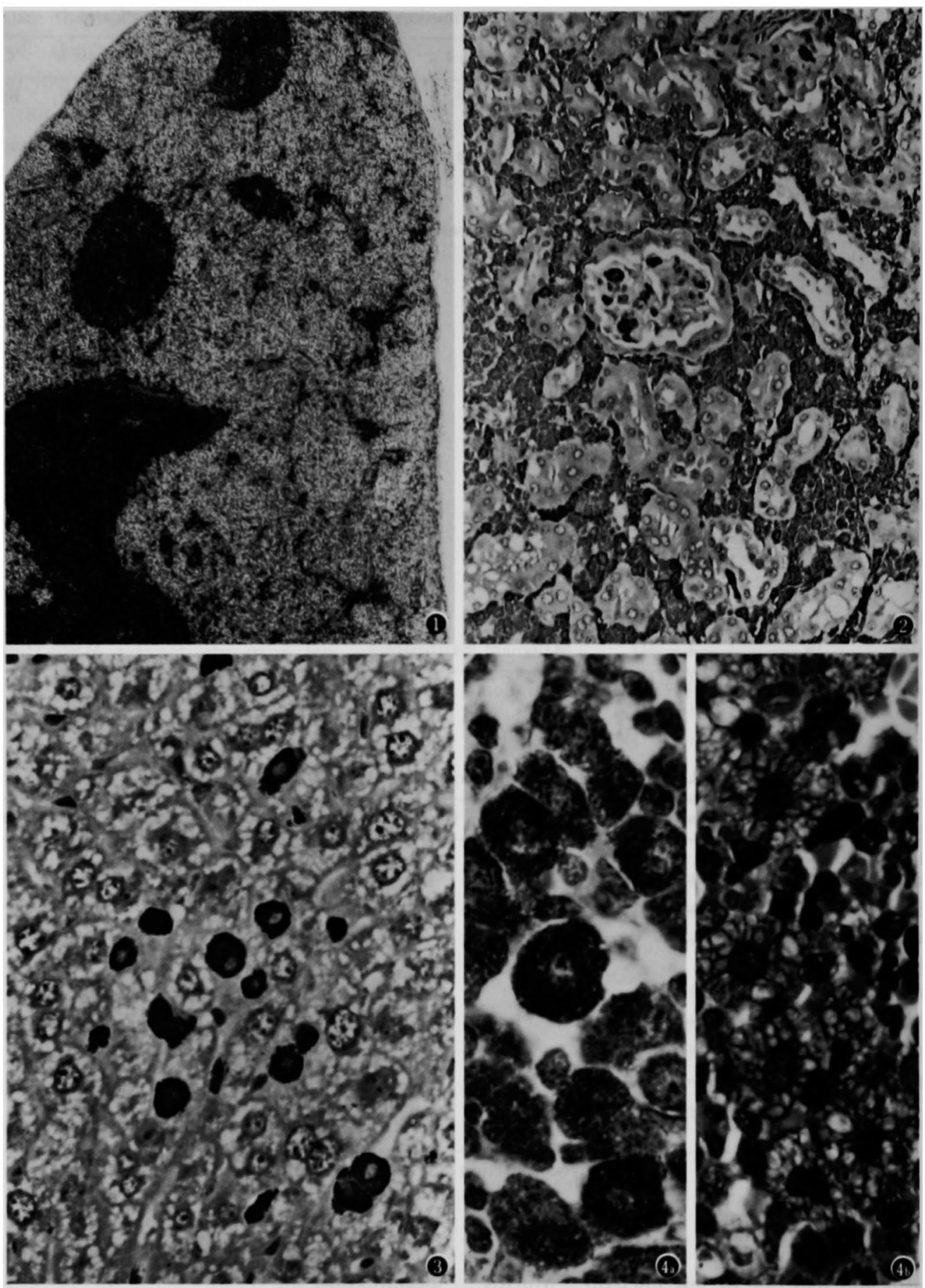

Fig. 1. Massive mast cell proliferation in sinus of red pulp of spleen. H.E., $\times 40$.

Fig. 2. Mast cell infiltration in the stromal area of cortex and glomerulus of kidney. Toluidine -blue, $\times 200$.

Fig. 3. Diffuse mast cell infiltration in sinusoids of liver. Toluidine-blue. $\times 200$.

Fig. 4. (a) Abundant fine granules showing marked metachromasia by toluidine-blue stain. (b) Vacuolar change of the cytoplasm. Toluidine-blue, $\times 1,000$. 


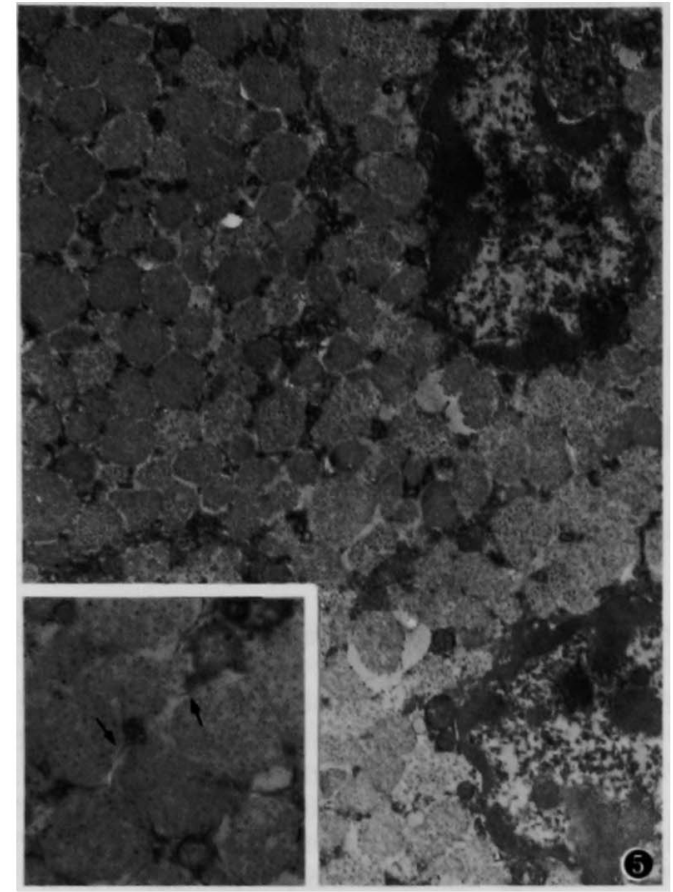

Fig. 5. A fine granular structure in the cytoplasm. Insert: Granular structures are enveloped in membrane-like structure (arrow).

without the so-called "lamellar structure" as seen in the mast cell of human. The granules appeared pale and were enveloped in a membrane-like structure (Fig. 5).

As for other histological findings observed in these animals with mast cell tumor, a variety of spontaneous lesions were encountered. Among them, ulceration of the stomach or skin may have any pathognomonic relationship with the mast cell tumor. However, no specific histological lesions, which may be induced with the drugs, were observed in any of the animals belonging to the same groups as those of mast cell tumor cases.

\section{Discussion and Conclusion}

Mastocytoma occurs as a solitary tumor mass, which may be either a localized manifestation of disseminated mast cell disease or a solitary benign tumor of tissue mast cell. Malignant mastocytosis occurs as a systemic progressive proliferation of atypical tissue mast cells in the hematopoietic organs and in many other tissues ${ }^{10}$. In this study, seven cases of mast cell tumors were diagnosed as malignant mastocytosis, and the other two cases were diagnosed as mastocytoma. These neoplastic cells had large cytoplasms and clear nuclei when compared with normal mast cells, but cytoplasmic granules were very fine similar to those in normal mast cells of the mice. These neoplastic mast cells seem to be well-differentiated and should be distinguished from those of hyperplastic aggregation accompanied with a variety of cells including fibroblasts, histiocytes, granulocytes, lymphocytes, and plasma cells ${ }^{3}$.

Based on our observations, a paucity of infiltration of eosinophilic leukocyte, proliferation of collagen fibers and edema and other stromal reactions as compared with mast cell tumor of the dog, swine or other animals may be the characteristic features of mast cell tumors in mice ${ }^{11-14,17,18}$. The stromal reactions that are found in other animals have been suggested to be caused by heparin, histamine or other biological activators, which are produced by the tumor cells and act through the discharge of cytoplasmic granules ${ }^{10,10}$. In this study, the paucity of these stromal reactions was recognized, although histamine, heparin, and serotonin were found to be positive in some cases. This paucity might be due to the fact that vacuolic changes surrounding the nucleus or discharge of granules were not found.

On the other hand, in mice as well as in other animals, mast cell tumors tend to grow particularly in the tissues having hematopoietic property like as the sinusoids of the spleen and liver as well as bone marrow. Further, mast cell tumor in mice is similar to those seen in feline since this tumor occurs more frequently in the male than in female and infiltration of eosinophils as a stromal reaction is mild ${ }^{15,10}$.

Among the few reports on spontaneous malignant mast cell tumor in mice. Deringer and Dunn described five cases in 861 reciprocal $F_{1}$ hybrid mice of strain $A$ and $L^{6,7}$ (1947). Lewis and Offer described four cases in 20,000 mice from CD-1, B6C3F $_{1}$ and CFLP strain mices (1984). In these reports, all cases were systemic forms of mast cell tumor involving the spleen, liver, kidney, lymph node, and other organs, and the most frequent site was the spleen. The neoplastic mast cells were described as well-differentiated with abundant metachromatic granules as in this report. As to 
associated lesions, Deringer and Dunn pointed out the hemorrhagic reaction of the lung in one case', and Lewis and Offer described necrosis and fibrosis of the marrow cavity in two cases ${ }^{8}$. The presence of neoplastic mast cells in peripheral blood was documented in both papers. In the present study, neoplastic mast cells were observed frequently in the glomerular capillary of the kidney, alveolar wall of the lung, and sinusoid of the liver, spleen, and bone marrow. Consequently. spontaneous malignant mastocytosis in mice was considered to be a leukemic disease. The term "mast cell leukemia" is used in some classification of mast cell tumor and is used as a synonym of malignant mast cell tumor ${ }^{15.20-22}$. The origin of mast cell has been suggested to be the bune marrow by Kitamura. Y. el al. 23.24. However, the term "malignant mastocytosis" iv used in preference to the term mast cell leukemia. since the tumor was considered to be derived from tissue mast cells.4.

Acknowledgments : This work was supported by a grant from the Foundation of Interdixiplinary Research Institute of Environmental Sciences. We thank Mr. Takashi Hagiwara. Miss Yasuyo Suzuki. Miss Mutsumi Akahori. Miss Sanae Oribe. Mr. Toshio Yamamoto, and Mr. Hiroyuki Inoue for their technical assistance and helpful suggestions.

\section{Reference}

I. Dunn. TB and Potter, M: A transplantable mast cell neoplasm in the mouse. JNCI 18: 587-601, 1957.

2. Frith, CH, Sprowls, RW, and Breeden, CR: Mast cell neoplasia in mice. Lab Anim Sci $26: 478-481$. 1976.

3. Bogovski, P: Tumor of the skin. pp. 1-42. In : Pathology of Tumors in Laboratory Animals. Vol. 2 - Tumor of the Mouse - VS Turusov Ed, IARC Sci Publ No. 23. Lyon, 1979.

4. Ohmori. T. Mori. H, and Rivenson, A : A study of tobacco carcinogenesis, $X X$. Am J Pathol 102 : 381-387, 1981 .

5. Furth, J, Hagen, P, and Hirsch, E: Transplantable mastocytoma in the mouse containing histamine, heparin, 5-hydroxytryptamin. Proc Soc Exptl Biol Med 95: 824-828, 1957.

6. Deringer MK and Dunn, TB : Mast-cell neoplasia in mice. JNCI $7: 289-298,1947$.

7. Dunn. TB: Mast cell neoplasia in mice. Natl Cancer Inst Monogr 32 : 285-287. 1969.

8. Lewis. DJ and Offer. JM : Malignant mastocytoma in mice. J Comp Pathol 94: 615-620, 1984.
9. Hubner, G. Electron microscopy of formalin-fixed human tissue. International symposium on electron microscopy and cytochemistry. J Histochem Cyto. chem 14: 757-758, 1966.

10. Mathe', G, Rappaport, H. O'Conor, GT, and Tor. loni, H: Malignant mastocytosis, pp. 36 . In : Histological and Cytological Typing of Neoplastic Disease of Hematopoietic and Lymphoid Tissues,International Histological Classification of Tumors - WHO Geneva, 1976.

11. Ames. TR and O'leary, TP : Mastocytoma in a cow a case. Can J Comp Med 48 : 115-117, 1984.

12. Bundza, A and Dukes. TW: Cutaneous and systemic porine mastocytosis. Vet Pathol 19: 453455. 1982.

13. Migaki, G and Carey, AM: Malignant mastocytoma in a cow. Am J Vet Res 33: 253-256, 1972.

14. Migaki, G and Langheinrich, KA : Mastocytoma in a pig. Pathol Vet 7: 353-355, 1970.

15. Moulton, JE and Dungworth, DL: Tumors of the lymphoid and hemopoietic tissue. pp. 150-204. In: Tumors in Domestic Animals, 2nd ed JE Moulton Ed, Univ. California Press, Berkeley, 1978.

16. Nielsen, SW : Disease of skin. pp. 581-618. In : Pathology of Laboratory Animals, Vol. 2, K Benirschke. FM Garner, and TC Jones Ed, SpringerVerlag. New York, 1978.

17. Nomura. Y. Sawaya, H. Kurashige, H, Tsuchiya, T, and Saitoo, $Y$ : Two cases of swine malignant mastocylosis. In : Proc. of Japanese Society of Veterinary Science. the 85th annual meeting (Tokyo). pp. 189. 1978.

18. Osame, S. Ishikawa. T. Ichijo. S. Taniyama, H, and Harada, M: Mastocytoma in a cow. J Jpn Vet Med Assoc 39: 247-251. 1986.

19. Kitamura. Y and Matsuda, H : Mastocytoma. pp. 227. In : Hematology of Experimental Animals. $M$ Seki, K Hirashima, and K Kobayashi, Ed. Soft Science. Tokyo, 1981.

20. Jones, TC and Hunt, RD : The skin and its appendages. pp. 1078-1134. In : Veterinary Pathology, Sth ed. Lea \& Febiger, Philadelphia, 1983.

21. Porta, GD, Chieco-Bianch, L, and Pennelli, N : Tumor of the haematopoietic system. pp. 527-576. In : Pathology of Tumors in Laboratory Animals, Vol. 2 - Tumor of the Mouse - . VS Turusov Ed, IARC Sci Publ No. 23. Lyon, 1979.

22. Frith, CH, Pattengale, PK, and $\mathbf{W}$ ard, JM: Neoplastic lesions. pp. 12. In : A Color Atlas of Hematopoietic Pathology of Mice. Toxicology Pathology Associates, Arkansas, 1985.

23. Kitamura. Y : Origin of mast cells. Jpn J Clin Sci 14: 1116-1119, 1978.

24. Kitamura, $Y$, Yokoyama, $Y$, and Sonoda, $T$ : Origin and differentiation of mast cells. Jpn J Cell 13 : $6-12,1981$. 